\title{
Investigation of the tick-borne encephalitis virus in Norway
}

\author{
Marina Sidorenko ${ }^{1}$, \\ Jana Radzievskaja ${ }^{1}$,
}

Olav Rosef ${ }^{1,2}$,

Algimantas Paulauskas ${ }^{1^{*}}$

${ }^{1}$ Vytautas Magnus University, Faculty of Natural Sciences, Vileikos St. 8, Kaunas 44404, Lithuania

${ }^{2}$ Rosef Field Research station, 4828, Mjåvatn, Norway
Expansion of the range of Ixodes ricinus ticks further north and to higher altitudes affects the spread of tick-borne encephalitis virus (TBEV) in new territories and increases the risk of human infections. Over the past decade, the number of tick-borne encephalitis (TBE) cases has increased in Norway and parts of the southern coast have been established as endemic. The aims of this study were to confirm the existence of TBEV endemic foci, determine the spread of TBE in different localities of Norway, review and compare relevant published records on the prevalence of TBEV in the different developmental stages and sex of the ticks. Ticks were collected from nine locations along the southern coast of Norway during June-July 2009. For the detection of TBEV-specific RNA, a real-time RT-PCR targeting a part of the 3 ' non-coding region of the TBEV genome was used. A total of 1542 ticks grouped in 250 pools were examined and TBEV RNA was detected in 5 pools with overall prevalence of $0.32 \%$.

Keywords: tick-borne encephalitis, Ixodes ricinus, prevalence of TBEV, Tromøy, Norway

\section{INTRODUCTION}

Tick-borne encephalitis (TBE) is one of the most dangerous human infections involving the central nervous system. The etiological agent, tick-borne encephalitis virus, is a member of the virus genus Flavivirus of the family Flaviviridae (Gritsun et al., 2003). Two different types of hosts are needed for the survival of TBEV: ticks that act as virus vector and reservoir hosts, and vertebrates (small rodent species) that act as a reservoir and a source of blood for feeding ticks and support TBEV transmission by co-feeding infected and non-infected ticks on the same host (Labuda et al., 2003). Humans are accidental viral hosts (Randolph et al., 2000). The majority of TBEV infections occur

\footnotetext{
*Corresponding author. Email: algimantas.paulauskas@vdu.lt
}

through a tick bite (either Ixodes persulcatus or Ixodes ricinus), although a small number of infections develop through consumption of infected unpasteurized milk (Dumpis et al., 1999) and occur in natural foci characterized by ecologic habitats favourable for ticks (Süss, 2010).

TBE becomes one of the most important diseases of humans in many parts of Europe and has been currently identified as a major health problem in many countries (Süss, 2003). Today, TBE is endemic in 27 European countries (Amicizia et al., 2013). Norway represents the northern limit in the geographical distribution of I. ricinus ticks in Europe. Expansion of the range of these ticks further north and to higher altitudes affects the spread of TBEV in new territories (Jore et al., 2011). This may increase the TBE caused by an expanding tick population, promoted by factors 
including climate change, social and political changes, and changes in land use (Süss, 2008). In Norway, TBE is a notifiable disease and it was first diagnosed in 1997 (Skarpaas et al., 2006). From 1998 to 2008, 45 cases of TBE were notified in Norway (Blystad et al., 2009). Between 1997 and 2007, 28 cases were reported from the southern coast and in the municipality of Tromøy Island (Gideon Informatics Inc. www.gideononline.com, 2017). According to the Norwegian Surveillance System for Communicable Diseases, the annual number of reported cases of TBE in Norway has increased from 2 to 14 during the last ten years (Norwegian Institute of Public Health).

Although TBE is a rare disease in Norway, the situation should to be monitored carefully (Skarpaas et al., 2004). Since the prevalence of TBEV in ticks is a suitable marker for TBE risk analysis in natural foci, systematic examination of ticks will help to develop further un- derstanding of the prevailing epidemiological situation (Andreassen et al., 2012). The aims of this study were to confirm the existence of TBEV endemic foci, to determine prevalence of TBEV in ticks collected from different locations in southern Norway, and compile and review relevant published records on the prevalence of TBEV in the different development stages and sex of the ticks.

\section{MATERIALS AND METHODS}

\section{Tick collection}

The ticks were collected at nine locations of Norway in East (Aust) and West (Vest) Agder counties during June-July 2009. (Table, Figure). A total of 1542 ticks (554 females, 437 males, 544 nymphs, and 7 larvae) were collected in nine sampling locations. Ticks were collected by flagging through forest and meadow vegetation and cooled to $4-6^{\circ} \mathrm{C}$. They were

Table. The number of ticks tested for tick-borne encephalitis virus, by developmental stage, number of pools assayed, number of positive pools

\begin{tabular}{|c|c|c|c|c|c|c|c|c|c|}
\hline Location & $\begin{array}{c}\mathrm{Fe}- \\
\text { male }\end{array}$ & $\begin{array}{c}\mathrm{Np} / \\
\mathrm{np}\end{array}$ & Male & $\begin{array}{c}\mathrm{Np} / \\
\mathrm{np}\end{array}$ & Nymphs & $\begin{array}{c}\mathrm{Np} / \\
\mathrm{np}\end{array}$ & Larvae & $\begin{array}{l}\mathrm{Np} / \\
\mathrm{np}\end{array}$ & Total \\
\hline $\begin{array}{c}\text { 1. SKJERNØY I } \\
\mathrm{N}-58^{\circ} 01.334^{\prime} ; \mathrm{E}-007^{\circ} 32.771^{\prime}\end{array}$ & 141 & $28 / 2$ & 96 & $19 / 0$ & 105 & $10 / 0$ & & & $342 / 2$ \\
\hline $\begin{array}{c}\text { 2. SKJERNØY II } \\
\mathrm{N}-58^{\circ} 00.603^{\prime} ; \mathrm{E}-007^{\circ} 31.221\end{array}$ & 16 & $3 / 1$ & 8 & $2 / 0$ & 59 & $6 / 0$ & & & $83 / 1$ \\
\hline $\begin{array}{c}\text { 3. TROMØY I } \\
\mathrm{N}-58^{\circ} 27.744^{\prime} ; \mathrm{E}-008^{\circ} 51.492^{\prime}\end{array}$ & 90 & $18 / 0$ & 75 & $15 / 0$ & 60 & $6 / 0$ & & & 225 \\
\hline $\begin{array}{c}\text { 4. TROMØY II } \\
\mathrm{N}-58^{\circ} 30.870^{\prime} ; \mathrm{E}-008^{\circ} 56.266^{\prime}\end{array}$ & 36 & $7 / 0$ & 45 & $9 / 0$ & 133 & $13 / 0$ & 7 & $1 / 0$ & 221 \\
\hline $\begin{array}{c}\text { 5. TROMØY III } \\
\mathrm{N}-58^{\circ} 29.230^{\prime} ; \mathrm{E}-008^{\circ} 52.194^{\prime}\end{array}$ & 66 & $13 / 0$ & 51 & $10 / 0$ & 35 & $3 / 1$ & & & $152 / 1$ \\
\hline $\begin{array}{c}\text { 6. GRIMSTAD } \\
\mathrm{N}-58^{\circ} 21.384^{\prime} ; \mathrm{E}-008^{\circ} 38.419^{\prime}\end{array}$ & 65 & $13 / 1$ & 58 & $12 / 0$ & 17 & $2 / 0$ & & & $140 / 1$ \\
\hline $\begin{array}{c}\text { 7. LILESAND } \\
\mathrm{N}-58^{\circ} 12.767^{\prime} ; \mathrm{E}-008^{\circ} 22.305^{\prime}\end{array}$ & 97 & $19 / 0$ & 64 & $13 / 0$ & 67 & $6 / 0$ & & & 228 \\
\hline $\begin{array}{c}\text { 8. KRISTIANSAND } \\
\mathrm{N}-58^{\circ} 15.266^{\prime} ; \mathrm{E}-007^{\circ} 54.834^{\prime}\end{array}$ & 30 & $5 / 0$ & 29 & $6 / 0$ & 46 & $4 / 0$ & & & 105 \\
\hline $\begin{array}{c}\text { 9. ODDERØYA } \\
\mathrm{N}-58^{\circ} 10.944^{\prime} ; \mathrm{E}-008^{\circ} 09.713^{\prime}\end{array}$ & 13 & $3 / 0$ & 11 & $2 / 0$ & 22 & $2 / 0$ & & & 46 \\
\hline Total & 554 & 109 & 437 & 88 & 544 & 52 & 7 & 1 & $1542 / 250 / 5$ \\
\hline
\end{tabular}

$\mathrm{Np}$ - number of pools, $\mathrm{np}$ - number of positive. 


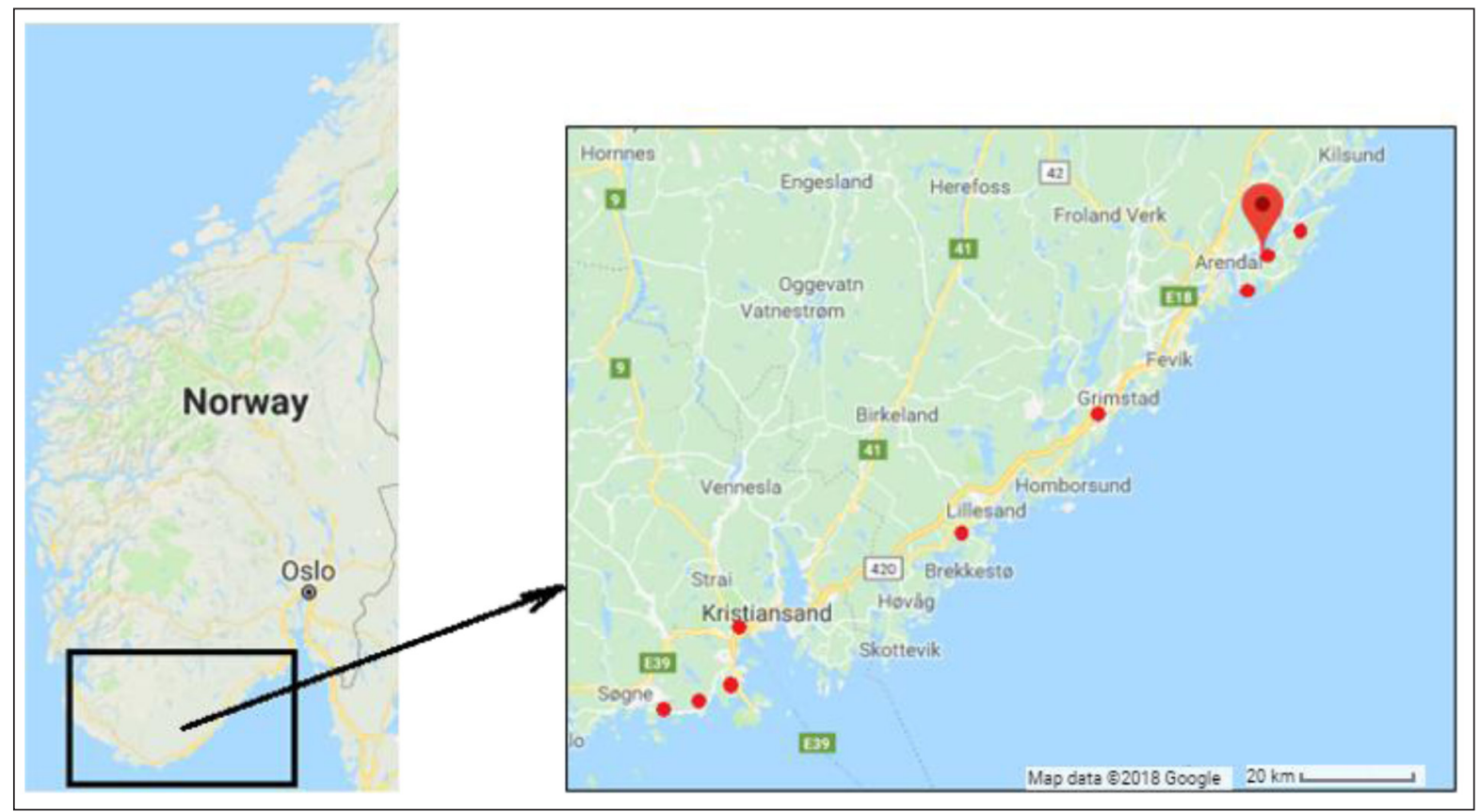

Figure. Locations in Norway, East (Aust) and West (Vest) Agder counties, where ticks were collected during June-July 2009

maintained alive until later identification. In the laboratory, ticks were sorted into larvae, nymphs, females, and males using a microscope, and stored at $-80^{\circ} \mathrm{C}$. The time between collection of live ticks and storage at $-80^{\circ} \mathrm{C}$ was no longer than $24 \mathrm{~h}$. Ticks were pooled into groups according to the sampling site, the development stage and sex by five males or females per pool and 10 nymphs per pool.

\section{Tick identification}

Ticks were classified by their development stage and sex using a microscope. Keys (Fillipova, 1977; Hillyard, 1996) were used for the identification of their morphological characteristics.

\section{RNA extraction}

Liquid nitrogen was added to the frozen ticks and homogenized immediately (without thawing). The frozen samples were powdered manually using a ceramic mortar and a pestle. Liquid nitrogen was continuously added to prevent thawing. RNeasy Mini Plant Kit (Qiagen, Hilden, Germany) was used for RNA extraction from the pools according to the manufacturer's instructions. The RNA was eluted with $40 \mu \mathrm{L}$ of distilled water and stored at $-80^{\circ} \mathrm{C}$ until use.

\section{Real-time reverse transcription-PCR}

For the identification of TBEV-specific RNA, F-TBE1 (5'-GGG CGG TTC TTG TTC TCC3') and R-TBE1 (5'-ACA CAT CAC CTC CTT GTC AGA CT-3') primers and a TBE-ProbeWT (FAM-TGA GCC ACC ATC ACC CAG ACA CA-BHQ1/TAMRA) of a quantitative real-time reverse transcription-PCR (RT-PCR) protocol according to Schwaiger and Cassinotti (2003) were used.

This method targets a part of the 3 " noncoding region of the TBEV genome that is conserved in essentially all TBEV subtypes and the amplicon is located at nt 11054-11123 of the Neudoerfl (European) subtype of TBEV (accession number U27495). RNAs of the TBEV genome-positive samples were used for a onestep RT-PCR as positive control.

TBEV RNA was amplified in a $25 \mu \mathrm{l}$ reaction mixture containing $5 \mu \mathrm{l}$ of each sample RNA, $12.5 \mu \mathrm{l}$ of $2 \mathrm{X}$ Reaction Mix (Invitrogen, England), $1 \mu \mathrm{l}$ of SuperScript III Platinum One-Step Taq Mix (Invitrogen, England), $0.5 \mu \mathrm{l}$ 
$(2.5 \mathrm{pmol} / \mu \mathrm{l})$ of forward primer (F-TBE 1$)$, $0.5 \mu \mathrm{l}(2.5 \mathrm{pmol} / \mu \mathrm{l})$ reverse (R-TBE 1$), 1 \mu \mathrm{l}$ ( $2 \mathrm{pmol} / \mu \mathrm{l}$ ) of TBE-WT probe, $4.5 \mu \mathrm{l}$ distilled $\mathrm{H}_{2} \mathrm{O}$ and $5 \mu \mathrm{l}$ of the sample RNA.

All one-step PCR reactions were carried out in a 96-well plate, which was centrifuged for $30 \mathrm{~s}$ at $1000 \mathrm{~g}$ at room temperature in a swingout rotor to remove small air bubbles in the reaction vessels. StepOnePlus ${ }^{\mathrm{TM}}$ Real Time PCR system (Applied Biosystems, USA) was used for PCR reactions and fluorescent detections with the following conditions: 1 cycle, reverse transcription, $50^{\circ} \mathrm{C}-30 \mathrm{~min} ; 2$ cycles, inactivation of reverse transcription, and Taq polymerase activation $94^{\circ} \mathrm{C}-2 \mathrm{~min} ; 42$ cycles: $94^{\circ} \mathrm{C}-30 \mathrm{~s}$, $57^{\circ} \mathrm{C}-30 \mathrm{~s}, 68^{\circ} \mathrm{C}-30 \mathrm{~s}$.

\section{Pooled prevalence calculations}

The TBEV prevalence in ticks was calculated as a minimum infection rate (MIR). MIR is a widely used method for estimating the proportion of infected individuals from pooled samples. It is calculated as the ratio of the number of positive pools to the total number of ticks tested. The underlying assumption of the MIR is that only one infected individual exists in a positive pool (Weidong et al., 2003).

Minimum Infection Rate (MIR):

$\operatorname{MIR}=(x /(m k)) 100 \%$

$k=$ pool size, $m=$ the number of pools tested, $x=$ the number of positive pool.

\section{RESULTS AND DISCUSSION}

All collected ticks were identified as I. ricinus. A total of 1542 ticks were pooled with five male or female adults or ten nymphs in each (250 pools). TBEV RNA was detected in five pools (2\%) (Table). Four positive pools from female ticks $(1.6 \%)$ and one from nymphs $(0.4 \%)$ were detected.

In $I$. ricinus in Europe, TBEV prevalence in unfed ticks varies between $0.1 \%$ and $5 \%$ (Süss 2010). In the present study, the MIR of TBEV from nine locations was $0.32 \%(5 / 1542)$.

The first cases of human tick-borne encephalitis in Norway were reported from Tromøy (Csángó et al., 2004). Skarpaas with collabora- tors estimated the prevalence in this site to be 0.2-0.3\% (Skarpaas et al., 2006). Seroprevalence studies indicate that Tromøy and some spots along the coast in the southernmost part of VestAgder County may have a higher incidence of TBE than the rest of the county (Skarpaas et al., 2004). In this study, TBEV was detected at four collection sites Skjernøy-I, Skjernøy-II, Tromøy II , Grimstad out of nine with prevalence $0.6 \%, 1.2 \%, 0.66 \%, 0.71 \%$, respectively.

Our study confirms the prevalence of TBEV in ticks from different locations in Southern Norway.

Although the prevalence of TBEV is a suitable marker for TBE risk analysis in natural foci (Oehme et al., 2003; Klaus et al., 2010), it cannot be directly translated into a risk for the population (Andreassen et al., 2012).

Reviewing and analyzing published records we found that in Norway, the prevalence of TBEV in I. ricinus in 2009 was $0.53 \%$ in pools of nymphs (Andreassen et al., 2012). In the autumn of 2001, virus prevalence of unfed free-living nymphs was $0.38(0.08-1.1 \%)$ and of adults $1.17(0.03-6.38 \%)$ in some districts near Passau in Bavaria (Süss et al., 2004). In 2011, three of 37 pools (two with nymphs, one with adult females) were found TBEV RNA-positive in Tokkekøb, (Denmark). Five of eight pools obtained from the second flagging session (all nymphs) in Tokkekøb were TBEV PCR-positive (Fomsgaard et al., 2013). In 2008, 2,074 nymphs and 906 adults I. ricinus were collected from 29 localities in Sweden and analyzed. The MIR for TBEV in nymphs and adult was $0.23 \%$ for Southern Sweden. The infection prevalence of TBEV was significantly lower in nymphs $(0.10 \%)$ than in adult ticks (0.55\%). At a well-known TBEV-endemic locality, Torö island south-east of Stockholm, the TBEV prevalence (MIR) was $0.51 \%$ in nymphs and $4.48 \%$ in adults of $I$. ricinus (Pettersen et al., 2014). From 2006 to 2009, ticks were collected throughout the territories of Estonia, Latvia, Lithuania, and Poland. Estonian ticks were found positive with an overall MIR of $1.55 \%$. The TBEV prevalence in adult and nymphal ticks was $0.46 \%$ and 0.48 , respectively 
(Katargina et al., 2013). For Latvia, the overall MIR of TBEV was $1.07 \%$. The prevalence in adult and nymphs of I. ricinus was significant different, $2.06 \%$ and $0.38 \%$, respectively (Katargina et al., 2013).

The presence of TBEV in Lithuania gives us an overall MIR of $0.30 \%$, with $0.32 \%$ in adults and $0.28 \%$ in nymphs (Katargina et al., 2013). In Poland, the overall MIR was $0.21 \%$, in adult and nymph stages $0.17 \%$ and $0.25 \%$, respectively (Katargina et al., 2013).

Comparative behaviour of different lifecycle stages of Ixodes ricinus to human-produced stimuli, were assessed in 22 ticks (eight nymphs, five adult males and nine females (Vasallo et al., 2002)). Statistical analyses demonstrated that a human host elicits different behavioural responses from ticks at different development stages. Irrespective of the stimulus, nymphs were more attracted to a human than adult ticks (Vassallo et al., 2002). Analyzing our data and that from other studies we can, however, assume that epidemiologically adult ticks are the most dangerous development stage for transmission of TBE to humans.

In the present study we provided data on prevalence of TBEV in male and female ticks: the infection rate in female ticks by MIR was $0.7 \%$, while in males TBEV was not detected (Table). Other researchers, from our reviewing published records, did not provide such data.

The risk of human infection is the product of the hazard (number of infected ticks, which is a product of tick abundance and pathogen infection prevalence) and contact rate between the infected ticks and humans (Dobson et al., 2011). More contacts between humans and ticks, abundance of ticks and their hosts may play a significant role in local spread of TBE and other tick-borne diseases. It is also known that infected ticks can be carried over long distances by migrating birds and thus establishing new foci of TBE (Klaus et al., 2016).

The results of the present study prove the presence of TBEV in four locations in Southern Norway and broaden the current knowledge on the dissemination of tick-borne encephalitis. The public need to be informed on how to avoid tick bites. In 2009 the Norwegian Institute of Public Health changed its TBE vaccination recommendations. Previously, TBE vaccination was recommended only for travelers who could expect to be exposed abroad. Since June 2009, vaccination against TBE has also been considered for people who often walk in forests and experience tick bites in the municipalities in Norway where TBE is endemic (Blystad et al., 2009).

Received 9 February 2018 Accepted 11 April 2018

\section{References}

1. Andreassen A, Jore S, Cuber P, Dudman S, Tengs T, Isaksen K, Hygen HO, Viljugrein $\mathrm{H}$, Ånestad G, Ottesen P Vainio K. Prevalence of tick borne encephalitis virus in tick nymphs in relation to climatic factors on the southern coast of Norway. Parasit Vectors. 2012; 5: 177.

2. Amicizia D, Domnich A, Panatto D, Luigi Lai P, Cristina ML, Avio U, Gasparini R. Epidemiology of tick-borne encephalitis (TBE) in Europe and its prevention by available vaccines. Hum Vaccin Immunother. 2013 May 1; 9(5): 1163-71.

3. Blystad H, Nygård K, Vold L. Tick-borne Encephalitis in Norway. EpiNorth. 2009; 10(2): 75-6.

4. Csángó PA, Blakstad E, Kirtz GC, Pedersen JE, Czette B. Tick-borne encephalitis in Southern Norway. Emerg Infect Dis. 2004 Mar; 10(3): 533-4.

5. Dobson AD, Taylor JL, Randolph SE. Tick (Ixodes ricinus) abundance and seasonality at recreational sites in the UK: hazards in relation to fine-scale habitat types revealed by complementary sampling methods. Ticks Tick Borne Dis. 2011; 2: 67-74. doi: 10.1016/j.ttbdis.2011.03.002.

6. Dumpis U, Crook D, Oksi J. Tick-borne encephalitis. Clin Infect Dis. 1999; 28: 882-90. 
7. Fillipova N. Ixodic ticks of the subfamily Ixodinae. Fauna in the USSR. Arachnidea, Vol. 4. Leningrad: Nauka, 1977.

8. Fomsgaard A, Fertner ME, Essbauer S, Nielsen YA, Frey S, Lindblom P, Lindgren PE, Bødker R, Weidmann M, Dobler G. Tick-borne encephalitis virus, Zealand, Denmark, 2011. Emerg Infect Dis. 2013 Jul; 19(7): 1171-3.

9. Gideon Informatics Inc. www.gideononline. com, 2017. [cited 2017 Dec 27]

10. Gritsun TS, Lashkevich VA, Gould EA. Tickborne encephalitis. Antiviral Res. January 2003; 57(1-2): 129-46.

11. Gu W, Lampman R, Novak RJ. Problems in estimating mosquito infection rates using minimum infection rate. J Med Entomol. 2003; 40(5): 595-596.

12. Hillyard PD. 1996. Ticks of North-West Europe. Barnes RSK and Crothers JH (eds.). Synopses of the British fauna, vol. 52. Field Studies Council, Shrewsbury, p. 1-178.

13. Jore S, Viljugrein H, Hofshagen M, BrunHansen H, Kristoffersen AB, Nygard K, Brun E, Ottesen P, Savik BK, Ytrehus B. Multi-source analysis reveals latitudinal shifts in range of Ixodes ricinus at its northern distribution limit. Parasit Vectors. 2011; 4: 84.

14. Katargina O, Russakova S, Geller J, Kondrusik M, Zajkowska J, Zygutiene M, Bormane A, Trofimova J, Golovljova I. Detection and characterization of tick-borne encephalitis virus in Baltic countries and Eastern Poland. PLoS One. 2013; 8(5): e61374.

15. Klaus C, Hoffmann B, Hering U, Mielke B, Sachse K, Beer M, Süss J. Tick-borne encephalitis (TBE) virus prevalence and virus genome characterization in field-collected ticks (Ixodes ricinus) from risk, non-risk and former risk areas of TBE, and in ticks removed from humans in Germany. Clin Microbiol Infect. 2010; 16: 238-44.

16. Klaus C, Gethmann J, Hoffmann B, Ziegler U, Heller M, and Beer M. Tick infestation in birds and prevalence of pathogens in ticks collected from different places in Germany. Parasit Res. 2016; 115: 2729-40.

17. Labuda M, Daniclova V, Jones LD, Nuttall PA. Amplification of tick-borne encephalitis virus infection during co-effiding of ticks. Med Vet Entomol. 1993; 7: 339-42.

18. Norwegian Institute of Public Health. Norwegian Surveillance System for Communicable Diseases (MSIS) 2012. http://www.msis.no. [cited 2017 Dec 27]

19. Oehme R, Hartelt K, Backe H, Brockmann S, Kimmig P. Foci of tick-borne diseases in southwest Germany. Int J Med Microbiol. 2002; 291(Suppl 33): 22-9.

20. Ormaasen V, Brantsæter AB, Moen EW Tickborne encephalitis in Norway. Tidsskr Nor Laegeforen. 2001; 121: 807-9.

21. Pettersson JH, Golovljova I, Vene S, Jaenson TG. Prevalence of tick-borne encephalitis virus in Ixodes ricinus ticks in northern Europe with particular reference to Southern Sweden. Parasit Vectors. 2014 Mar 11; 7: 102. doi: 10.1186/1756-3305-7-102.

22. Randolph SE, Rogers DJ. Fragile transmission cycles of tick-borne encephalitis virus may be disrupted by predicted climate change. Proc Biol Sci. 2000; 267: 1741-4. doi: 10.1098/ rspb.2000.1204.

23. Schwaiger M, Cassinotti P. Development of a quantitative real-time RT-PCR assay with internal control for the laboratory detection of tick-borne encephalitis virus (TBEV) RNA. J Clin Virol. 2003; 27: 136-45.

24. Skarpaas T, Ljøstad U, Sundøy A. First human cases of tickborne encephalitis, Norway. Emerg Infect Dis. 2004 Dec; 10(12): 2241-3.

25. Skarpaas T, Golovljova I, Vene S, Ljostad U, Sjursen H, Plyusnin A, Lundkvist A. Tickborne encephalitis virus, Norway and Denmark. Emerg Infect Dis. 2006; 12: 1136-8. 10.3201/eid1207.051567.

26. Süss J. Epidemiology and ecology of TBE relevant to the production of effective vaccines. 
Vaccine 2003; 21(Suppl 1): S19-35 doi:10.1016/ S0264-410X(02)00812-5.

27. Süss J. 2008. Tick-born encephalitis in Europe and beyond - the epidemiological situation as of 2007. Euro Surveill. 2008 Jun 26; 13(26). 18916.

28. Süss J. Tick-borne encephalitis 2010: Epidemiology, risk areas, and virus strains in Europe and Asia - an overview. Ticks Tick Borne Dis. March 2011; 2(1): 2-15.

29. Süss J, Schrader C, Falk U, Wohanka N. Tickborne encephalitis (TBE) in Germany - epidemiological data, development of risk areas and virus prevalence in field-collected ticks and in ticks removed from humans. Int J Med Microbiol. April 2004; 293(Suppl 37): 69-79.

30. Vassallo M, Pérez-Eid C. Comparative behavior of different life-cycle stages of Ixodes ricinus (Acari: Ixodidae) to human-produced stimuli. J Med Entomol. 2002 Jan; 39(1): 234-6.

\section{Marina Sidorenko, Jana Radzievskaja,} Olav Rosef, Algimantas Paulauskas

\section{ERKINIO ENCEFALITO TYRIMAI NORVEGI- JOJE}

\section{Santrauka}

Ištirtas Ixodes ricinus erkių diapazono bei erkinio encefalito viruso (EEV) plitimas i naujas šiaurines teritorijas. Tyrimo metu buvo patvirtinti EEV endeminiai židiniai Pietų Norvegijoje, atsižvelgiant ị erkių vystymosi etapus ir lytị, atlikta lyginamoji EEV paplitimo analizè. 2009 m. birželio-liepos mèn. erkès buvo surinktos iš devynių vietų Pietų Norvegijos pakrantèje. EEV specifinei RNR nustatyti naudotas tikro laiko PGR, nukreiptas ị 3” nekoduojančio EEV genomo regiono dalị. Ištirtos 1542 erkès buvo sugrupuotos i 250 grupes. EEV RNR aptikta 5 grupèse, bendras EEV paplitimas yra 0,32\%.

Raktažodžiai: erkinis encefalitas, Ixodes ricinus, erkinio encefalito viruso paplitimas, Tromøy, Norvegija 